\title{
O ESPELHO, ENTRE GALEANO E LACAN
}

\section{THE MIRROR, BETWEEN GALEANO AND LACAN}

\author{
Heloisa Helena Ribeiro de MIRANDA ${ }^{1}$ \\ Célia Maria Domingues da Rocha REIS ${ }^{2}$ \\ Luís Fernando Barnetche BARTH ${ }^{3}$
}

\begin{abstract}
RESUM0: Neste artigo propomos a análise e interpretação de poemas do escritor uruguaio Eduardo Galeano, com o intuito de demonstrar, em sua poética, no âmbito das representações do eu, a construção da alteridade, partindo da teoria lacaniana de constituição do sujeito. Pelas análises perceberemos a luta travada pelo eu na busca do reconhecimento de si mesmo.

Palavras-chave: Eduardo Galeano, poesia e subjetivação.
\end{abstract}

\begin{abstract}
The text that follows is proposing a reading of poems of Uruguayan writer Eduardo Galeano, in order to demonstrate how the construction of other ness in his poetic manifestations and representations of the self occurs, based on the Lacanian theory the constitution of the subject. The analyzes realize the struggle for the self in quest for recognition of yourself.
\end{abstract}

\footnotetext{
${ }^{1}$ UFMT - Universidade Federal de Mato Grosso. Instituto de Linguagens - Programa de Pós-Graduação em Estudos de Linguagem. Cuiabá - MT-Brasil. 78600-000 heloisamiranda@hotmail.com.

2 UFMT - Universidade Federal de Mato Grosso. Instituto de Linguagens Departamento de Letras.- Programa de Pós-graduação em Estudos de Linguagem - Cuiabá-MT - Brasil. 78065900 - celiadr@uol.com.br.

${ }^{3}$ UFMT - Universidade Federal de Mato Grosso. Instituto de Ciências Sociais Departamento de Psicologia. Rondonópolis-MT - Programa de Pós-graduação em Estudos de Linguagem - Cuiabá-MT-Brasil. 78735901- luisfernandobarth@gmail. com.
} 
Keywords: Eduardo Galeano, poesy and subjectivity.

\section{0 espelho e a imagem do nada}

Desde sua invenção no século XIV, pelos venezianos, o espelho sempre exerceu um fascínio sobre nós. Nosso reflexo produzido por esse artefato seduz-nos. Esse poder de sedução nos foi demonstrado, primeiro, pelo mito de Narciso. Na história mitológica, a água exerceu a função de refletir a imagem de Narciso, oferecendo-lhe um outro desconhecido, que correspondia à imagem de si mesmo. Num instante hipnótico produzido por sua aparência, Narciso é absorvido por esse outro, o qual não reconhece como sendo ele mesmo.

O espelho possui essa característica hipnótica, produzida no instante da contemplação do eu. No entanto, ele possui uma ambiguidade, visto que a imagem por ele oferecida é um reflexo invertido e ilusório de nós. Mas, por que essa imagem é invertida e ilusória? Por que não podemos acreditar no que vemos no espelho? Clement Rosset traz a seguinte concepção:

[...] o espelho é enganador e constitui uma falsa evidência, quer dizer, a ilusão de uma visão: ele me mostra não o eu, mas um inverso, um outro, não meu corpo mas uma superfície, um reflexo. Ele é apenas uma última chance de me apreender, que sempre acabará por decepcionarme, qualquer que seja a jubilação que pude experimentar. (1988, p. 65)

0 que o artefato nos proporciona nada mais é que uma representação vazia de nós, a qual não é percebida como o nada; acreditamos que o reflexo que temos é real, e essa percepção é instaurada pela ânsia do nosso reconhecimento. Nós, como sujeitos, necessitamos desse reconhecimento como meio de construção e consolidação de nossa identidade.

As ações de nos vermos e nos reconhecermos nessa representação, apaziguam nosso espírito, já que acreditamos que aquilo que vemos somos nós, um instante de nossa exatidão. 
Entretanto, o eu representado pelo espelho não diz respeito ao eu da consciência, este que acreditamos ser, mas corresponde ao "mim", ou seja, um eu vazio, destituído de subjetividade. De fato, desde pequenos somos enganados por esse "falsificador". Lacan (1998) fala acerca de como somos introduzidos nesse universo especular, o qual será o responsável pelo nosso processo de subjetivação. 0 teórico explica que o infans, a criança que ainda não fala, quando ainda se encontra em fase de lactação, é antecipada por seu cuidador a se reconhecer na imagem que o espelho produz de si. Afirma que, geralmente, isso ocorre a partir dos seis meses de idade, quando o bebê ainda não possui uma postura corporal consolidada, e seu cuidador o segura, diante do espelho, mostrando uma imagem integrada de si. Essa atitude caracteriza o que Lacan chama de uma identificação, uma vez que, a partir de então, a criança adquire uma imagem, tratada pela psicanálise de imago, "[...] um esquema imaginário adquirido, um cliché estático através do qual o indivíduo visa o outro" (LAPLANCHE E PONTALIS, s.d., p. 305). A partir de então, ela é levada constantemente a associar a imagem que vê no espelho a si mesma.

A assunção jubilatória de sua imagem especular por esse ser mergulhado na impotência motora e na dependência da amamentação que é filhote do homem nesse estágio de infans parecer-nos-á, pois, manifestar numa situação exemplar, a matriz simbólica que o [eu] se precipita numa forma primordial, antes de se objetivar na dialética da identificação como o outro e antes que a linguagem lhe restitua, no universo, sua função de sujeito. (LACAN, 1998, p. 97)

Assim, o infans é precipitado no processo de constituição do eu antes mesmo de se inserir no universo da linguagem; ele passa a reconhecer a imagem como sendo ele próprio, pois ela possibilita formular, imageticamente, uma unidade corporal por identificação com a imagem do outro. Desse modo, o pequeno é lançado, precipitadamente, ao universo alienante da linguagem, que será 
responsável pela constituição do eu na relação especular com o outro.

Mas o ponto importante é que essa forma situa a instância do eu, desde antes de sua determinação social, numa linha de ficção, para sempre redutível para o indivíduo isolado - ou melhor, que só se unirá assintoticamente ao devir do sujeito, qualquer que seja o sucesso das sínteses dialéticas pelas quais ele tenha que resolver, na condição de [eu], sua discordância de sua própria realidade. (LACAN, 1998, p.98)

É esse simulacro que possibilita o processo de subjetivação do indivíduo, uma vez que ele só se constitui a partir da imagem do outro. Para Lacan, é o fato de convivermos em sociedade que possibilita a consolidação do eu, justamente porque será a partir da observação das experiências do outro e das relações estabelecidas com ele que vamos edificando o nosso eu. $\mathrm{O}$ aspecto assintomático está relacionado à não percepção do sujeito dessa relação especular entre ele e o outro.

O espelho é objeto que encontra guarida em poemas do uruguaio Eduardo Galeano, localizado nessa relação do eu e do outro. Perguntamo-nos, então, como tal relação se dá e que analogias podemos estabelecer entre o eu e a miragem vazia, trazida pelo espelho. Outras duas indagações se colocam: de que modo o eu se comporta diante dessa imago? 0 que tal imagem é para o eu?

No início do texto, tratamos da característica hipnótica que o espelho exerce sobre o sujeito. Essa característica diz respeito ao ato de sermos envolvidos involuntariamente por algo, como se fôssemos extraídos da nossa realidade e lançados em outra, na qual não teríamos controle racional sobre o eu. Dessa maneira, o espelho cria a ilusão de que somos a imagem que ele nos devolve, uma ilusão necessária para o processo de constituição do sujeito.

Na obra de Galeano, o espelho se apresenta com esse poder hipnótico, sendo a ação sobre o eu tão intensa que chega ao seu aprisionamento. Vejamos como isso acontece no poema intitulado “Ventana sobre el espejo”, da obra Las palabras andantes (1993, p. 205) 
Solea el sol y se lleva los restos de sombra que ha dejado la noche.

Los carros de caballos recogen, puerta por puerta, la basura.

En el aire tiene la araña sus hilos de baba.

El Tornillo camina las calles de Melo. En el pueblo lo tiene por loco. Él lleva um espejo en la mano y se mira com el ceño fruncido. No quita los ojos del espejo.

- ¿Qué haces Tonillo?

_ Aquí_dice. Controlando al enemigo.

O poema demonstra o efeito de hipnose sofrido pelo eu-lírico em relação ao eu ofertado pelo espelho. Os versos revelam um primeiro plano, com uma terceira pessoa do singular enunciadora, que apresenta em cena sumária a situação do eu, primeira pessoa do discurso. A voz em terceira pessoa compõe a representatividade do outro, o qual possui como função questionar as ações do eu. É o outro de si mesmo que o questiona. Não é o eu quem fala, mas sim o outro que observa e analisa.

$\mathrm{Na}$ obra, o eu leva em sua mão um espelho, artefato que representa o falo psicanalítico. 0 falo é o objeto de desejo, a ânsia do sujeito pelo preenchimento, mesmo que momentâneo, da ausência instaurada em si, no ato de seu nascimento. Quando nascemos, perdemos definitivamente a segurança encontrada no ventre da mãe. No instante do corte do cordão umbilical, sofremos uma separação. Segundo Lacan, essa separação só poderá ser preenchida com a inserção do indivíduo no mundo da linguagem.

O conceito lacaniano de sujeito como falta-a-ser é útil aqui: o sujeito fracassa em se desenvolver como um alguém, como um ser específico; no sentido mais radical, ele não é, ele é não-ser. 0 sujeito existe - na medida em que a palavra o moldou do nada, e é possível falar ou discursar sobre o sujeito - embora permaneça sem-ser. Antes da alienação não havia a menor possibilidade de ser: é o próprio sujeito que está lá no início. (FINK, 1998, p. 74) 
O espelho é oferecido ao sujeito como um meio de preenchimento que o leva para além dessa ausência e lhe proporciona uma sensação de completude. Tal sensação só é possível pela ação reflexivo-analítica do verbo se mira, no presente do indicativo, o qual estrutura o fato, concretizando o instante do aprisionamento do eu pela imagem produzida no espelho. Não obstante, o mirarse não é apenas a ação de ver, mas trata-se de um ato reflexivo do eu-lírico, observado pelo outro, em relação a si mesmo, que não se reconhece na imagem, e, por isso, traz o ceño frunzido.

A forma de expressão facial é o índice do não reconhecimento de si, o não-ser tratado por Lacan, o qual, por mais que não se reconheça na imagem refletida pelo espelho, sente-se hipnotizado por ela.

No quita los ojos del espejo

A hipnose é causada pelo não reconhecimento. Quem é este que vejo de mim senão eu? Esse é o questionamento que o eu-lírico faz a si mesmo, sua hipótese, enfatizada por outro questionamento que lhe é feito no poema:

- ¿Qué haces Tonillo?

_ Aquí_dice. Controlando al enemigo.

Os dois versos seguintes respondem ao porquê de não se reconhecer. A miragem que lhe é oferecida não é reconhecida como sendo ele mesmo, mas como um outro. A reflexão é tão intensa, que o eu observado e analisado pelo eu-lírico é compreendido por ele como sendo seu inimigo, um eu inimigo de mim. Não obstante, existe um desejo de dominação do eu em relação a esse duplo representado pela imagem. A ação reflexiva de se olhar com severidade expressa a vontade de dominar esse outro. Freud teve a mesma sensação quando estava de viagem em um trem e não percebeu que a imagem que ele não reconheceu refletida pelo vidro era dele mesmo. 
Freud se estranha no espelho, e tal estranhamento acompanha sempre, ainda que de maneira sutil, o reconhecimento no espelho que inaugura o eu. Quando este se constitui, ele ao mesmo tempo se estranha, dividindo-se na imagem, figurando nela a operação que o divide por sua entrada na linguagem, no simbólico, denominada por Freud de castração. (RIVERA, 2007, p. 318)

Se a imagem que vemos no espelho é a do não-eu considerado pelo eu-lírico um inimigo, por que, então, é o ato de se reconhecer nele que inaugura a constituição do eu? Essa representação pode ou não ser concebida como real?

Se considerarmos o estudo de Michel Foucault (1999) quanto à possibilidade de essa imagem vir a ser real, ele afirma que não, pois a representação do objeto não mantém relações com o real, afirmando que ela é um simulacro vazio. Sendo assim, a imagem que o eu-lírico vê de si mesmo nada mais é que uma imagem vazia de si mesmo. Entretanto, Lacan (1998) afirma que haveria uma chance de essa imagem ser percebida como o real.

Como se há de recordar, o referido experimento, montagem de prestidigitador como o chama o próprio Lacan, onde se manipula, graças a um espelho côncavo a composição de uma figura híbrida de ilusionista, metade objeto real, metade imagem, destina-se a ilustrar "um mundo em que o imaginário pode incluir o real e, ao mesmo tempo, formá-lo" [...] a metáfora ótica de Lacan diz o mesmo, a saber, a constituição da identidade através da alteridade por duplicação de uma imagem própria que o indivíduo carregaria consigo. (ARANTES, 1995, p. 19)

Desse modo, o eu-especular vazio, na concepção de Foucault, pode ser considerado como uma representação que mantém proximidade com o eu, e é esta proximidade que permite ao eulírico se identificar com o reflexo, o qual não é o real, mas ainda pode sustentar uma relação com ele. 
A percepção que temos na leitura dos textos de Eduardo Galeano é a de que o eu, o qual não é reconhecido como sendo ele mesmo, mas, sim, como um inimigo, vai se distanciando cada vez mais de si mesmo, consolidando mais e mais o outro no contato com o espelho.

yo no encuentro mi cara en el espejo.

Na medida em que o eu vai se distanciando de si mesmo, o outro vai adquirindo consistência, como se estivesse construindo uma identidade independente do eu; por isso, ele não se encontra, ele não está lá, pois já é outro.

Nesta primeira análise, percebemos que a representação desse eu, que vai sendo construído na poética de Galeano, é ofertada nessa analogia com o espelho. Parece-nos que o espelho fracassa em sustentar o retorno de uma imagem com a qual ele poderia ser identificado. De tal relação especular surge, então, o outro poderoso que passa a dominar o eu, levando-o a não se reconhecer. Entretanto, de que modo o outro pode tomar para si a consciência do eu? Isso é o que compreenderemos a seguir.

\section{Eu, apetite perpétuo de ser outro}

Quem é este outro, senão o eu mesmo? Na verdade, eu não sou eu mesmo, mas, sim, outro, como já nos referimos anteriormente. O que pretendemos, agora, é compreender como este outro, a alteridade, edifica-se na obra de Galeano; de que maneira a alteridade, por meio da linguagem, propicia a materialidade do poético, expresso nos poemas e como ocorre a formação dessa e/ ou dessas representações do eu em convívio com o outro.

Segundo Octavio Paz (2005, p. 100), nos tempos antigos, o mundo possuía uma forma e um centro definido, seu movimento era estável e o homem tinha uma percepção palpável do universo. Com o desenvolvimento industrial, tecnológico, esse modo de percepção se expande e o seu horizonte, antes delimitado, abrese ao infinito. Transforma-se a imagem que o homem tinha de si 
mesmo e do universo em sua unicidade. As formas de percepção da matéria - o tempo, torna-se descontínuo; e o espaço, desintegra-se e se expande.

Do esfacelamento na percepção do homem em relação ao mundo, às coisas e a si mesmo, o sentimento consequente é o de uma ausência ou fragmentação. Nesse contexto, o eu passa a criar representações singulares de si mesmo. Embora cada representação corresponda a um reflexo do próprio eu, esse reflexo é o que ameaça sua centralidade.

0 crescimento do eu ameaça a linguagem em sua dupla função: como diálogo e como monólogo. 0 primeiro se fundamenta na pluralidade; o segundo na identidade. A contradição do diálogo consiste que cada um fala consigo mesmo ao falar com os outros; a do monólogo de que nunca sou eu, mas outro o que escuta o que digo a mim mesmo. A poesia sempre foi uma tentativa de resolver esta discórdia através de uma conversão dos termos: o eu do diálogo no tu do monólogo. A poesia não diz: eu sou tu; diz: meu eu és tu. A imagem poética é a outridade. (PAZ, 2005, p.102)

Ameaçado em sua centralidade, o sujeito sente a ausência. A metáfora do "diálogo" e do "monólogo" é a maneira que o poeta encontrou para dizer que, quando falamos com nosso semelhante, falamos também conosco, já que vemos no outro o reflexo de nós mesmos; e quando nos dirigimos a nós mesmos, também estamos nos relacionando com as representações do eu que nos habita. Logo, a busca de si mesmo no outro é a tentativa do preenchimento da falta, que poderia ser suprida pela presença do outro, e que a palavra poética oportuniza, denominada pelo crítico de outridade.

Na teoria lacaniana, é esse outro que proporciona a formação e consolidação do eu. $\mathrm{O}$ eu é tratado de maneira dicotômica. 0 teórico compreende a existência de um eu, que corresponde ao eu consciente, denominado em língua francesa como moi; e de um outro [eu] o qual está relacionado ao próprio inconsciente, que é 
determinado por Lacan como sendo uma estrutura, denominada $j e$, a partir das possibilidades da língua francesa. 0 eu corresponde à suposta consciência que o sujeito tem de si mesmo. A respeito disso, afirma Lacan:

0 que corresponde ao eu é o que por vezes chamo a soma dos preconceitos que comporta todo saber, e que cada um de nós carrega individualmente. Trata-se de algo que inclui o que sabemos ou cremos saber - pois, saber é sempre, por algum lado, crer saber. (LACAN, 1985, p. 58)

Cremos que somos nós, acreditamos na imagem vazia que o espelho nos oferece. Entretanto, este eu nos é dado como um objeto, um instante efêmero de nossa exatidão; é a consciência como fenômeno físico que produz a tensão a qual mediatiza a apreensão momentânea do eu. 0 eu que suponho saber nunca está presente, pois está apenas no campo imaginário, no entanto, este eu é o responsável por registrar a consciência-de-si, trazendo a significação, que faz com que o sujeito acredite nesse eu oferecido pelo espelho.

O eu da consciência, em Galeano, é o não-ser; ele sabe que não o é, e tal percepção vai construindo uma angústia, a qual é vai sendo duramente aspergida em cada poema. Esse não-ser poder ser compreendido melhor a partir da análise do poema "La pálida", da obra El livro de los abrazos (1989, p. 57). Nele, o eu-lírico demonstra o sentimento de estar e não se perceber estando.

Mis certezas desayunan dudas. Y hay dias en que me siento Extranjero en Montevideo y em cualquier otra parte. En esos días, dias sin sol, noches sin luna, ningún lugar es mi lugar y no consigo reconocerme en nada, ni em nadie. Las palabras

no se parecen a lo que nombran y ni siquiera se parecen a su proprio sonido. Entonces no estoy donde estoy. Dejo mi cuerpo y me voy,

lejos, a ninguna parte, y no quiero estar con nadie, ni siquiera 
conmigo, y no tengo, ni quiero tener, nombre ninguno. Entonces

pierdo las ganas de llamarme o ser llamado.

Observemos atentamente cada linha poética, na qual o eu-lírico atesta a ânsia pela identificação, apoiando-se em las palabras. Mas por que se apoiar em palavras? Segundo Lacan (1998), é a nossa inserção no universo da linguagem que proporciona nossa composição enquanto sujeito. Para ele, a linguagem corresponde a uma ordem constituída por leis, que excluem o conceito, não sendo uma expressão natural e, por isso, não pode ser compreendida somente como um código.

Enquanto código, a linguagem possui como função a comunicação. No entanto, ela é muito mais, posto que é por meio dela que o sujeito existe como um ser social. A sociabilidade do sujeito só é possível porque ele consegue se relacionar com outros sujeitos. 0 ato de comunicar exige a participação dos agentes, não há comunicação sem esta participação. Como bem afirma Benveniste:

Antes de qualquer coisa, a linguagem significa, tal é seu caráter primordial, sua vocação original que transcende e explica todas as funções que ela assegura no meio humano. (...) para resumi-las em uma palavra, eu diria que, bem antes de servir para comunicar, a linguagem serve para viver. Se nós colocamos que à falta de linguagem não haveria nem possibilidade de sociedade, nem possibilidade de humanidade, é precisamente porque o próprio da linguagem é, antes de tudo, significar. Pela amplitude desta definição, pode-se medir a importância que deve caber à significação (1989, p. 222. Grifo nosso).

Se para Lacan (1998) o sujeito, enquanto ser social, só é possível devido à sua inserção na linguagem, e para Benveniste (1989), a linguagem é o que permite o "viver", logo, a linguagem se compõe como a estrutura do sujeito. Dessa maneira, o eu se compõe como uma imagem significante, uma estrutura destituída de conceito. A significação dessa imagem cabe ao outro. Aquilo que supomos 
ser, somo-lo porque são os outros que nos atribuem significado. Significar é existir e o eu só existe em virtude do outro.

É em virtude do significar que, desde o início, o homem buscou meios para nomear os seres e as coisas, por isso o eu-lírico se apoia nas palavras. Nomear significa dar materialidade à identidade de cada ser. $\mathrm{O}$ ato de nomear estabelece uma analogia entre o ser e o objeto nomeado, relação que possibilita a concretude da existência dos seres e das coisas. Foi o que Ferdinand Saussure denominou de signo. Para o linguista,

[...] os signos linguísticos, embora essencialmente psíquicos, não são abstrações, mas associações ratificadas pelo consentimento coletivo, o qual o conjunto constitui a língua, estas associações são realidades que têm sua rede na mente. (2006, p. 23)

No entanto, o signo trazido pelo eu-lírico como sendo o possuidor da identidade de si e das coisas não corresponde apenas à concepção dicotômica entre significado e significante do linguista, mas também ao seu aspecto simbólico. Lacan (1998) parte da teoria saussuriana para compreender o inconsciente como uma estrutura; desse modo, o teórico modifica a estrutura algorítmica do signo saussuriano, invertendo-a. Defende a predominância do significante em relação ao significado, ou seja, a estrutura do signo formada por Saussure (2006) de Significado/Significante é estruturada em Lacan (1998) como Significante/significado, uma vez que, para Lacan, os significantes são responsáveis pela formação de cadeias, que correspondem às imagens as quais estruturam o inconsciente.

Pois o algoritmo é senão pura função do significante, não pode revelar senão uma estrutura do significante a essa transferência. Ora, a estrutura do significante é, como se diz, comumente da linguagem, que seja articulada. Isso quer dizer que suas unidades, se partam de onde se partam para desempenhar suas invasões recíprocas e seus englobamentos crescentes, estão subtendidas à 
dupla condição de se reduzir a elementos diferenciais últimos e de os comporem segundo as leis de uma ordem fechada. (LACAN, 1998, p. 504)

As leis de ordem fechada dizem respeito à sintaxe edificada pelo inconsciente, as quais organizam a simbologia do mundo e lançam o pequeno sujeito no universo da linguagem, que só é possível pela alienação instaurada na relação especular do eu com o outro. Desse modo, a palavra para o eu-lírico representa a potência do significante que está para além da significação, e que corresponderia a uma verdade ${ }^{4}$ a qual o sujeito tem de si.

A verdade do eu-lírico é manifestada pelo sintoma do não reconhecimento. No entanto, o próprio eu não consegue realizar a identificação da causa de sua angústia. A não facilidade na sua identificação se deve à dificuldade de interpretar as imagens representadas pelo inconsciente. Nos poemas de Galeano, a verdade se especifica por ser poética, justamente por semidizer. 0 poema é uma saída encontrada pelo sujeito na busca por si mesmo, ou o mais próximo de onde ele pode chegar.

\section{Las palabras}

no se parecen a lo que nombran y ni siquiera se parecen a su proprio

sonido.

0 verbo parecer no presente do indicativo traz a necessidade da semelhança, da aproximação do nome com o objeto representado. Entretanto, essa analogia não é concretizada e o eu-lírico não reconhece las palabras. 0 nome não encontra seu referente na realidade que se representa, passando, então, a personificar uma outridade não identificada.

\footnotetext{
${ }^{4}$ Uma verdade, se é que é preciso dizê-lo; não é fácil de reconhecer, depois de ter sido aceita uma vez. Não que não haja verdades estabelecidas, mas, nesse caso, elas se confundem tão facilmente com a realidade que as cerca que, para distinguilas desta, por muito tempo não se encontrou outro artifício senão marcá-las com um sinal, signo de espírito e, para lhes prestar homenagens, tomá-las como vindas de outro mundo. (LACAN, 1998, p. 409)
} 
A imaginação poética não é invenção, mas descoberta da presença. Descobrir a imagem do mundo no que emerge como fragmento ou dispersão, perceber no uno o outro, será devolver à linguagem sua virtude metafórica: dar presença aos outros. A poesia: procura dos outros, descoberta da outridade. (PAZ, 2005, p. 102)

Para o crítico, a outridade é a materialidade poética que possibilita ao sujeito um apaziguar efêmero de si mesmo. Dessa maneira, pensando em Lacan (1998), o poema, como estrutura linguística metafórica que surge fragmentada, constitui-se como uma manifestação inesperada do inconsciente, e, logo, um caminho para o reencontro do eu consigo mesmo.

Quando percebemos a construção desse universo metafórico, materializado nos textos de Galeano, é que tomamos consciência do poder do signo enovelado pelo poético. A construção do poema é um meio de amenizar o sofrimento do eu-lírico de não se reconhecer. 0 não reconhecimento é também relacionado no poema aos sons produzidos por cada palavra, assim o som "[...] não é apenas um som que se assemelha a uma forma, mas uma relação de sons a uma relação de formas" (TODOROV, 1977, p. 57).

Na obra, as palavras não se reconhecem em seu som e nem em seu objeto. Se as palavras às quais confiamos o significado dos seres e das coisas perderam essa propriedade, como o eu-lírico conseguirá se identificar?

Entonces no estoy donde estoy.

É o fato de não se reconhecer que faz com que ele se abandone. Entretanto, esse abandono ocorre de duas maneiras: primeiro, corresponde não ao abandono do corpo físico, mas ao da identidade manifestada na imagem que ele oferece do eu, e é exatamente por sua identidade não estar na matéria que o constitui que o abandono se manifesta de outra forma, ou seja, o abandono da matéria também 
simboliza a busca pela identificação do eu e a libertação do espírito. De acordo com Rosset “[...] o verdadeiro eu só será captado no instante em que este se abandona porque o eu é apenas um reflexo entre outros, mudo e insignificante como eles." (1988, p. 75).

Observemos a arbitrariedade da ação: o eu-lírico não se identificando com o eu que lhe é dado, tenta encontrar outros meios na busca da consciência-de-si. Para tanto, procura uma maneira de se ausentar da matéria, com o intuito de ver-se de fora. Seria como se ele se projetasse para fora num ato reflexional de um eucircular, isto é, lanço meu eu para distante de mim para me fazer um outro; este outro é aquele que me observa e me analisa. Tal ato é o que Lacan (1985) chama de "intersubjetividade", que corresponde a um jogo de espelhos oferecido pela vida, no qual tudo estará relacionado ao desejo.

Não obstante, para a teoria lacaniana, a relação intersubjetiva ultrapassa a instância do eu, uma vez que o sujeito não é anterior ao mundo das formas que o fascinam, mas ele se constitui nelas e por elas. Lacan afirma que o exterior não está fora e, sim, no interior do sujeito. Desse modo, aquilo que exteriorizamos só é possível sê-lo, porque, antes de tudo, possuímos em nós mesmos essa estrutura que comanda a nossa relação com toda exterioridade real e a soma dos preconceitos que comporta todo saber.

É muito especial no plano imaginário que este para além da relação intersubjetiva seja atingido. Trata-se de um dessemelhante essencial, que não é nem o suplemento nem o complemento do semelhante, que é a própria imagem da deslocação, do rasgamento essencial do sujeito. 0 sujeito passa para além desta vidraça onde vê, amalgamada, sua própria imagem. É a cessação de qualquer interposição entre o sujeito e o mundo. (LACAN, 1985, p. 223)

Logo, é o não reconhecimento de si que instaura o desejo de se reconhecer, sendo o outro "amalgamado" pelo sujeito responsável pela sua interação com o mundo. Os versos seguintes do poema 
evidenciam o ato de abandonar-se, o qual constrói a existência não do eu da consciência, mas de um outro:

\section{Dejo mi cuerpo y me voy, \\ lejos,}

Deixando-se, o eu-lírico se afasta da racionalidade, representada pelo corpo, já que este é a parte de seu eu perceptível, sua superfície apreendida. 0 distanciamento é ressaltado pelo advérbio de lugar lejos, "longe", em português. 0 afastamento do eu da consciência propicia a manifestação do Grande Outro, o qual Lacan denomina inconsciente.

Para Lacan (1985), o inconsciente não é a consciência dominada pela razão; nem uma subjetividade monolítica; também não é uma psicologia profunda e muito menos uma substância espiritual. É, sim, um sistema psíquico distinto dos demais e dotado de atividade própria, sendo encontrado em estado bruto e impermeável a qualquer inteligibilidade. No inconsciente não haverá dicotomias, posto que é estruturado por uma sintaxe a qual está para além do sujeito, fora do controle da consciência. De acordo com o teórico, o inconsciente se manifestará esporadicamente por equívocos de linguagem, sonhos, atos falhos, ou sintomas, existindo em virtude do universo simbólico que a linguagem constrói. Lacan (2003) distingue três tipos de equívocos: homofônico, relacionado à ortografia do texto; gramatical, que materializa a maneira de organização das ideias; e o lógico, correspondendo à não contradição do inconsciente.

O inconsciente escapa totalmente a este campo no qual o homem se reconhece como um eu. É fora deste campo que existe algo que tem todos os direitos de se expressar por [eu] e que demonstra este direito pelo fato de vir à luz expressando-se a título de [eu]. (LACAN, 1985, p. 15)

Desse modo defendemos a ideia de que na obra de Galeano há uma equivocidade do autor que jogaria, propositalmente, com a 
lógica. Essa lógica é percebida na maneira com que o autor articula a linguagem e consegue compor recursos metalógicos expressivos, como podemos observar na construção do poema ora em análise. 0 nível metafórico que o escritor consegue alcançar nesse poema ultrapassa o mero trabalho retórico.

A ação de abandonar o corpo constrói uma imagem que não pode existir fora da realidade do texto. Por isso, a lógica assente a produção de outros sentidos e, mesmo, sentidos que ultrapassam a intenção consciente do autor. Logo, ela corresponde ao instante em que o inconsciente se manifesta por meio da linguagem, revelando sua astúcia que opera e comanda as representações do eu, que vão sendo deixadas em cada poema, cada qual formando um lugar simbólico distinto, estruturando representações diferenciadas.

Todavia, o inconsciente permanece imutável. Onde, então, estaria localizado o inconsciente? Na teoria freudiana (1996), o inconsciente estaria localizado em uma zona profunda, logo abaixo da consciência. Já na teoria lacaniana (1985), ele está na superfície e não no subterrâneo da psique, e se manifesta sem a consciência do sujeito, sendo independente.

\begin{abstract}
[...] o inconsciente é um lugar e um não lugar, completamente indiferente à realidade, que não conhece lógica, negação, causalidade ou contradição, totalmente entregue ao jogo instintivo dos impulsos e da busca do prazer. (EAGLETON, 2006, p. 236)
\end{abstract}

É neste lugar-não-lugar que ele se consolida, construindo o Grande Outro, o qual passa a dominar o eu. Esta outridade é tão poderosa que o faz não ele mesmo, mas outro. Segundo Lacan (1985), o eu da consciência é denominado de pequeno outro, estando perpetuamente alienado ao seu outro-ideal, "[...] o outro que não é outro coisa nenhuma, já que ele é essencialmente acoplado com o eu, numa relação sempre reflexiva, intercambiável - o ego é sempre um alter-ego." (LACAN, 1985, p. 401). Na teoria lacaniana, aqui considerada até meados de 1985, a imagem do pequeno outro 
é a própria imagem antecipada do eu - o eu é aspirado pela imagem do outro - é onde o corpo despedaçado do infans encontra sua totalidade e sua unidade, com o qual faz identificação imaginária, compondo, por efeito, a alienação.

Na obra de Galeano, esse desejo pelo outro se manifesta na busca incessante por si mesmo e no desejo da identificação com a imagem que o espelho lhe oferece. As representações desses eus configuram a ânsia por uma unidade, um todo completo. Não obstante, ao analisarmos os textos e observarmos como o autor vai compondo seus versos, damo-nos conta de que esse momento nunca acontecerá. Temos a impressão de que a distância vai se intensificando na proporção em que o desejo aumenta, como podemos perceber no verso seguinte:

yo no encuentro mi cara em el espejo.

0 eu-lírico sabe que o artefato dever-lhe-ia oferecer a imagem de si mesmo, mas ele não encontra ali sua face refletida. Não a encontra porque ela não está lá, o eu já é outro. Observemos que o poema traz o termo cara, justamente para lhe conferir familiaridade como objeto desejado, entretanto, nunca alcançado. Logo em seguida ele afirma:

Hablo lo que

no digo.

De que maneira é possível falar o que não se diz? Não é o eu-lírico quem fala, mas o Grande Outro, chegando a perceber a dimensão inconsciente representada por ele, essa entidade mítica da ordem do significante, que revela o ponto de origem do sujeito - sua espécie, sua linhagem, sua cultura, sua família - inserindo-o numa linha de ascendência e descendência, permitindo-lhe significar sua história geracional e sua ficção.

O sujeito é um elo do discurso do Grande Outro, no qual muitos estão encadeados: “[...] uma família inteira, um bando inteiro, uma 
facção inteira, uma nação inteira ou a metade do globo" (LACAN, 1985 p. 118). Desse modo, a realidade do inconsciente origina-se a partir de um complexo de muitas representações e, sobretudo, vai se configurando numa realidade fantasmática. 0 inconsciente será, então, um lugar que, na teoria lacaniana, é estruturado como um discurso, no qual o sujeito é pensado. É neste lugar que surgem as determinações simbólicas da história do sujeito e, então, o inconsciente se torna um arquivo dos ditos dos outros. É o pequeno outro que pensa e analisa diante da imagem vazia do reflexo, e, por isso, o eu-lírico não se reconhece.

0 inconsciente como discurso do Outro nos indica que não só ele é estruturado como uma linguagem, mas que o lugar do Outro equivale ao lugar do código pessoal dos significantes. 0 grande Outro é o conjunto de significantes que marcam o sujeito em sua história, seu desejo, seus ideais - eles sustentam suas fantasias inconscientes e imaginárias. (QUINET, 2012, p. 24)

O eu-lírico é determinado pelos significantes produzidos pelo Outro, compondo um eu mutável a cada instante. 0 Grande Outro corresponde às malhas da memória que vão sendo gravadas no sujeito, das experiências do eu em seu convívio social. Os significantes da teoria lacaniana são formados a partir da imagem que o eu-lírico tem de si, refletida na imagem do outro, ou seja, o eu-lírico se percebe do modo como é percebido pelo outro. Mas por que a mutabilidade do eu? Por que ele nunca consegue ser exato? 0 que percebemos é que o eu é o reflexo do outro, uma vez que ele se compõe das imagens que lhe são devolvidas. E é por isso, que "[...] o sujeito se decompõe, se esvanece, se dissocia nos seus diversos eus." (LACAN, 1985, p. 223).

Estoy, pero no soy. Y subo a um tren que me lleva adonde no voy,

A seleção lexical denuncia a condição do eu-lírico; os verbos 
ser e estar, ambos na primeira pessoa do presente do indicativo revelam o eu. Ele sabe que está presente, sua realidade de ser lhe é apresentada, estoy. Aqui, o verbo estar manifesta sua característica de transitoriedade do estado dos seres e das coisas, reforçando o estado transitório do eu-poético. Já o verbo ser traz a carga da concretude do eu e sua relação com a realidade. Entretanto, a organização sintagmática dos termos desconstrói sua realidade e sua condição de sujeito, que é desfeita por meio da construção paratática adversativa, materializada pela conjunção pero. Este juntor introduz a dicotomia do não-ser lacaniano na construção do poema.

Dando continuidade ao estudo desse poema, nos versos que seguem, o eu-lírico nos confessa estar embarcando em um trem:

Y subo a um tren que me

lleva adonde no voy

A construção poética materializa uma viagem reflexiva, determinada pela concretude do substantivo tren. Este transporte adquiriu na história da humanidade uma idiossincrasia, uma vez que foi o primeiro meio motor a deslocar de um lugar ao outro uma grande quantidade de cargas e pessoas. 0 fato de viajar de tren traz consigo a característica de temporalidade e de deslocamento de um lugar para outro, ou de uma condição para outra. Neste caso, o tempo é destinado aos instantes de reflexão do eu-lírico, formando uma viagem simbólica de si-a-si-mesmo que o leva ao desconhecido, encaminhando-o em direção ao Grande Outro.

[...] o sujeito de que falávamos há pouco, como legatário da verdade reconhecida, justamente não é o eu perceptível nos dados mais ou menos imediatos do gozo consciente ou da alienação laboriosa. Essa distinção de fato é a mesma que se encontra entre o $\alpha$ do inconsciente freudiano, na medida em que ele se separa por um abismo das funções pré-conscientes, e o $\omega$ do testamento de Freud na 31 a de suas Newen Vorlesungen [Novas conferências]: "Wo Eswar, sollIchwerden." (LACAN, 1998, p. 418) 
O que Lacan nos diz é que Freud já havia se referido à distinção entre o eu da consciência do sujeito, imaginário em sua composição, e o [eu] do inconsciente relacionado ao universo simbólico. Dizer que a verdade do [eu] está onde o eu não está significa que, para chegarmos o mais próximo da verdade do sujeito, ele deve estar destituído do significado alienante que o supõe, e deixar emergir o significante simbólico e ilusório da verdade do-si-mesmo. No caso de Eduardo Galeano, o sintoma do não-ser demonstra a tentativa de abandonar o eu da consciência, buscando, assim, sua verdade como sujeito. Daí a construção simbólica da viagem e o abandono do corpo, na ânsia de compreender seu verdadeiro [eu].

No poema, o substantivo tren é indeterminado pelo artigo indefinido un que, nasalizado, transmite a sensação de interioridade. Ao pronunciarmos o fonema nasal, sentimos a nasalização do som que percorre o corpo. Alfredo Bosi (2000) lembra-nos da importância da simbologia sonora na construção da palavra poética, afirmando que "[...] o som do signo guarda, na sua aerada e ondulante matéria, o calor e o sabor de uma viagem noturna pelos corredores do corpo" (2000, p. 52). A partir de então, a travessia interminável é iniciada, uma vez que o eu-lírico é lançado no jogo do desejo do-si-mesmo. 0 desejo na teoria psicanalítica é a energia motora da vida. Nascendo da falta, o sujeito passa a lutar para suprimi-la. Mas que falta? É a ausência da sensação de completude do sujeito, instaurada pela castração; é essa lacuna que nos movimenta como sujeitos. Passamos a vida em busca desse objeto, o qual nos ofereceria uma suposta satisfação.

[...] É o objeto que viria no lugar do objeto perdido de uma primeira e suposta satisfação completa, mas nunca o reencontramos a não ser tão somente seus substitutos transitórios e fugazes." (QUINET, 2012, p. 34)

Em nossa vida procuramos um outro no qual possamos encontrar o amor e a segurança tão desejados. No entanto, o 
que encontramos são substitutos incompletos como nós.

O Outro não constitui um universo completo, e sim um furado - pois falta um significante que permitiria dizer que é um conjunto totalizante de todos os significantes da linguagem. [...] No inconsciente, como discurso do Outro, sempre falta um significante último que daria um último sentido à vida, à história e às questões do sujeito. (QUINET, 2012, p. 30)

\section{Algumas considerações finais}

Na obra de Eduardo Galeano, é a falta deste último significante que o motiva na busca de si mesmo, propiciando a construção de sua poética. A expressão da falta transborda pelos poemas, que conseguem organizar o sentimento e materializá-lo em múltiplas metáforas. Cada poema construído é uma tentativa de exatidão do eu. A exatidão corresponderia ao instante em que o eu acredita ter preenchido a ausência de seu ser. A construção de um poema se edifica como um simulacro do eu. $\mathrm{O}$ eu duplicado pelo poema compõe a imagem do-si-mesmo, permitindo, de modo imaginário, a sensação de exatidão.

Assim, podemos compreender como a outridade vai, paulatinamente, convencendo o eu da consciência a buscar os significantes efêmeros. Quando o eu-lírico se olha no espelho e reconhece a si mesmo como inimigo, ele demonstra a força do Grande Outro que se manifesta aí, convencendo-o de que este é um engodo. 0 alcançar é o que define a construção da outridade na obra poética de Eduardo Galeano. Lançar-se nesse jogo significa existir. É o jogo da busca pelo eu que movimenta a vida, ao mesmo tempo em que a sua não existência simboliza a morte do sujeito. Desse modo, compreendemos que cada texto escrito pelo autor é a materialidade de cada representação do eu que tenta alcançar sua identificação com o outro. 


\section{REFERÊNCIAS BIBLIOGRÁFICAS}

ARANTES, Paulo Eduardo. Hegel no espelho do Dr. Lacan. In: Psicologia USP. v 6, São Paulo: Edusp, 1995, p. 11-38.

BENVENISTE, Émile. Problemas de lingüística geral. Vol I, Campinas, SP: Pontes, 1989.

BOSI, Alfredo. 0 ser e o tempo da poesia. 6ed. São Paulo: Companhia das letras, 2000.

EAGLETON, Terry. Teoria Literária: uma introdução. São Paulo: Martins Fontes, 1997.

FINK, Bruce. 0 sujeito lacaniano: entre a linguagem e o gozo. Tradução Maria de Lourdes Sette Câmara. Rio de Janeiro: Zahar, 1998.

FOUCAULT, Michel. A linguagem tornada objeto. In: As palavras e as coisas: uma arqueologia das ciências humanas. Trad. Salma Tannus Muchail. 8ed. São Paulo: Martins Fontes, 1999, p.408-416.

GALEANO, Eduardo H. El libro de los abrazos. Madrid: Siglo XXI, 1989.

. Las palabras andantes. Buenos Aires: Siglo XXI, 1993.

LACAN, Jacques. Escritos. Tradução de Edition Du Seuil. Rio de Janeiro: Jorge Zahar, 1966.

O seminário. Livro 1. Os escritos técnicos de Freud.

Versão brasileira de Betty Milan. Rio de Janeiro: Jorge Zahar, 1998. 
GALEANO, Eduardo H. 0 aturdito. In: Outros Escritos. Rio de Janeiro: Jorge Zahar Editor, 2003, p. 448-500.

O seminário. Livro 2. 0 Eu na teoria de Freud e na técnica da psicanálise. (1954-1955). Tradutores, Marie Christine LaznikPenot; com a colaboração de Antonio Luiz Quinet de Andrade. Rio de Janeiro: Jorge Zahar Editor, 1985.

LAPLANCHE, J. \& PONTALIS, J.-B. Vocabulário da psicanálise. São Paulo: Livraria Martins Fontes, sd.

PAZ, Octavio. Signos em rotação. Tradução Sebastião Uchoa Leite. Org. Celso Lafer e Haroldo de Campos. São Paulo: Perspectiva, 2005.

QUINET, Antonio. Os outros em Lacan. Rio de Janeiro: Zahar, 2012.

ROSSET, Clement. 0 real e seu duplo: ensaio sobre a ilusão. Apresentação e tradução de José Tomaz Brum. 2ed, Rio de Janeiro: José Olimpio, 2008.

RIVERA, Tania. Ensaio sobre sublimação. In: Discurso. São Paulo: Almeida, 2007, p. 312-324.

TOVOROV, Tzvetan. FÓNAGY, Ivan. COHEN, Jean. Linguagem e motivação: uma perspectiva semiológica. Porto Alegre: Globo, 1977 